\title{
Association between Residual Feed Intake and Some Biochemical Metabolites of Growing Hamari Lambs
}

Balgees Abu Elgasim Atta Elmnan ( $\nabla$ balgeesatta@gmail.com )

Istituto per il Sistema Produzione Animale in Ambiente Mediterraneo Consiglio Nazionale delle Ricerche https://orcid.org/0000-0002-0324-6984

Tayseer Abass Karar Ali

University of Khartoum

Research article

Keywords: residual feed intake, FCR, GFE, blood serum metabolites

Posted Date: October 15th, 2020

DOI: https://doi.org/10.21203/rs.3.rs-46169/v1

License: (a) (1) This work is licensed under a Creative Commons Attribution 4.0 International License. Read Full License 


\section{Abstract}

Background

Recently the use of residual feed intake (RFI) trait for the identification of animal that are more efficient in feed utilization has received much attention from scientist. Since basal metabolic processes are responsible for a large proportion of energy requirements; blood metabolites that reflect the workload placed on them may give indication of differences in animal efficiency. The objectives of this study were to estimate the differences in growth performance, some blood metabolites indices in growing Hammari lambs selected for high, medium and low residual feed intake (RFI). Moreover, correlation between RFI, feed conversion ratio (FCR), gross feed efficiency (GFE) and some blood indices was carried out.

\section{Results}

The results indicated there were no significant differences among RFI classes for initial BW $(P=0.69)$ final $B W(P=0.84)$ and $A D G(P=0.51)$. Significant differences among RFI classes were observed for DM intake, RFI $(P=0.001)$, FCR ratio $(P=0.01)$, and GFE $(P=0.03)$. Low RFI animals consumed, on average, $0.62 \mathrm{~kg} / \mathrm{d}$ DM less than high RFI animals. Low and med RFI animals had lower serum total protein $(P=0.01)$, globulin $(P=0.01)$, urea $(P=0.02)$, and aspartate aminotransferase (AST) $(P=0.01)$ levels than high RFI. A comparison of serum creatinine among RFI groups showed that the med and the low RFI groups had higher concentration than high RFI group. There were associations between RFI and the serum metabolites for total protein ( $\mathrm{rRFI}=0.44$ ), globulin $(\mathrm{rRFI}=0.31)$, urea $(\mathrm{rRFI}=0.40), \mathrm{AST}(\mathrm{rRFI}=0.76)$ and $\mathrm{HDL}(\mathrm{rRFI}=0.50)$. Also, associations between FCR and serum globulin $(\mathrm{rFCR}=0.31)$ and $\mathrm{AST}(\mathrm{rFCR}=$ 0.41 ) were detected. Results for serum mineral concentrations showed no significant $(P>0.05)$ differences among RFI classes. The same trend was observed to results of correlation between mineral metabolites and RFI, except for phosphorus, which was positively correlated with RFI (rRFI $=0.32$ ).

\section{Conclusion}

The study concluded that the low RFI animals had less concentration of serum total protein, globulin, urea, AST and HDL. All these measures showed that low RFI animals were more efficient in feed utilization, than high RFI animals.

\section{Background}

Sheep in Sudan constitute about $37 \%$ of total livestock numbers [1]. They are bred mainly for meat production, having a role in food security, highly demanded in local market and abroad. Sudanese sheep classified into four distinct ecotypes according to locality, one of these ecotypes Sudan desert sheep, which constitute $65 \%$ of sheep population in the country [2]. There are many sub types of Sudanese desert sheep in Kordofan state, and the major sub types Kabbashi and Hamari considered as a prototype of export [3].

The trend for rising costs associated with raising sheep have been decreasing profit margins in sheep industry, preventing expansion [4]. Decreasing inputs would increase the profitability of sheep production through the minimization of input costs since feed provision is one of the greatest costs of production [5]. Small improvements in feed efficiency can reduce the cost of gain considerably since the price of feed comprises 70 to $80 \%$ of the total gain cost [6]. Feed efficiency is an economically important trait for the animal feeder. It has been determined that a $5 \%$ improvement in feed efficiency is equivalent to any one of the following, reducing ration costs on a dry matter basis by $\$ 8$ per ton, reducing purchase costs of the feeder animal by $\$ 1.75 \mathrm{cwt}$ or increasing daily gain by 0.6 lbs per day [6].

The feed efficiency animals have an important influence on production and promote industry competitiveness that provides the potential to identify and select animals with high ability to convert feed into animal products [7]. The concept of residual feed intake (RFI) is one of tools that use to calculate the feed efficiency of growing animals. RFI is difference between observed feed intake and expected feed intake based on estimated maintenance and production requirements [8].

Animals classified as more efficient would be represented by a low RFI since they eat less than expected for the same growth while high RFI would be considered inefficient since they have intakes that are greater than expected. This feed efficiency trait represents variations in the requirements for basic metabolic processes rather than variations due to differences in level of production $[9,10,11]$. These requirements for background metabolic processes represent 60 to $70 \%$ of total energy expenditures [12] with a large proportion of individual variation due to differences in visceral organ metabolism [10, 13]. There is no phenotype link between RFI and characteristics used to calculate expected feed intake, which allows for comparison of animals that function at differing production numbers. This has led some authors to believe that RFI is representative of individual differences in metabolic processes of the animals [14]. Searching for physiological parameters such as blood becomes useful in better understanding the possible physiological variation in efficiency of diet use among individuals. Globally for sheep, there are few studies on feed efficiency from RFI [15, 16, 17].

Sudan has no previous studies on animal feed efficiency from RFI for different kind of animals. Therefore, the study was designed to evaluate the potential differences in feedlot performance, some blood metabolites of Hamari lambs classified into feed efficiency groups according to the RFI. Moreover, correlation studies between feed efficiency represented by RFI, FCR, GFE, and some blood parameters of Hamari lambs were calculated.

\section{Results}

\section{Performance traits and Residual feed intake:}

The results from present study indicated that all animals consumed a mean of $1.21 \mathrm{~kg}$ of ration (DM) per day during the study period; these values were close to range that reported by NRC [18]. 
During the residual feed intake (RFI) determination period, lambs in the low RFI group (16 animals) consumed on average, $0.62 \mathrm{~kg} / \mathrm{d}$ DM less feed than lambs in the high RFI group (10 animals), showing there is $14.28 \%$ variation in consumption between high and low RFI classes. No significant differences among RFI classes were observed for body weight (BW) at the beginning $(P=0.69)$ and at the end $(P=0.84)$, or $A D G(P=0.51)$ during the tested period (Table 1). With respect to the other efficiency measures studied, significant differences among RFI classes were observed for RFI $(P=0.001)$, FCR $(P=0.01)$, and GFE $(P=0.032)$. All these measures showed that low RFI animals were more efficient in feed utilization than medium (13 animals) and high RFI animals.

Table 1

Means and SEM of performance traits and feed efficiency of Hamari lambs of different residual feed intake (RFI) classes

\begin{tabular}{|c|c|c|c|c|c|c|c|c|}
\hline \multirow[t]{2}{*}{ Parameters } & \multicolumn{3}{|c|}{ RFI classes } & \multirow[b]{2}{*}{ SEM } & \multirow[b]{2}{*}{$\operatorname{Low}(n=16)$} & \multirow[b]{2}{*}{ SEM } & \multirow{2}{*}{$\begin{array}{l}\text { P- } \\
\text { Value }\end{array}$} & \multirow[t]{2}{*}{ Sig. } \\
\hline & $\operatorname{High}(n=10)$ & SEM & $\operatorname{Med}(n=13)$ & & & & & \\
\hline Initial BW(Kg) & 26.77 & 1.17 & 26.00 & 0.93 & 27.18 & 0.93 & 0.69 & NS \\
\hline $\mathrm{DMI}_{\mathrm{obs}}(\mathrm{Kg} /$ day $)$ & $1.28^{a}$ & 0.004 & $1.24^{b}$ & 0.003 & $1.12^{c}$ & 0.002 & 0.001 & ** \\
\hline ADG (Kg/day) & 0.19 & 0.01 & 0.20 & 0.01 & 0.21 & 0.01 & 0.51 & NS \\
\hline RFI (Kg/day) & $0.34^{a}$ & 0.05 & $0.09^{b}$ & 0.04 & $-0.28^{c}$ & 0.04 & 0.001 & ** \\
\hline Final BW(Kg) & 44.50 & 1.49 & 44.15 & 1.30 & 45.16 & 1.18 & 0.84 & NS \\
\hline GFE & $0.16^{c}$ & 0.01 & $0.17^{a b}$ & 0.01 & $0.18^{a}$ & 0.01 & 0.03 & * \\
\hline FCR & $6.87^{a}$ & 0.35 & $6.35^{a}$ & 0.31 & $5.47^{b}$ & 0.28 & 0.01 & * \\
\hline
\end{tabular}

BW: body weight, $\mathrm{DMI}_{\mathrm{obs}}$ : observed dry matter intake, ADG: average daily gain, RFI: residual feed intake, GFE: Gross feed efficiency and FCR: Feed

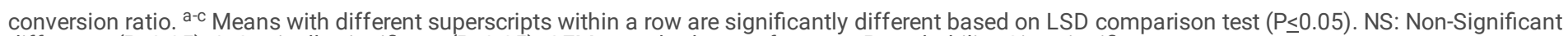
difference $(P>0.05)$. *: Statically significant $(P \leq 0.05)$. SEM: standard error of means. P: probability, Sig.: significance.

\section{Residual feed intake and blood metabolite parameters:}

The high RFI lambs significantly had a greater concentration of total serum protein $(P=0.01)$, globulin $(P=0.01)$, urea $(P=0.02)$ and aspartate aminotransferase (AST) $(P=0.01)$ than the lambs with a low RFI (Table 2). A comparison of serum creatinine concentrations among RFI groups showed that the med and the low RFI groups had higher concentration than high RFI group. While, no significant $(P>0.05)$ differences were found among RFI classes for serum creatine kinase enzyme (Table 2).

Table 2

Means and SEM of serum protein metabolites and some enzymes for Hamari lambs of different residual feed intake (RFI) classes

\begin{tabular}{|c|c|c|c|c|c|c|c|c|}
\hline \multirow[t]{2}{*}{ Parameters } & \multicolumn{6}{|l|}{ RFI classes } & \multirow[t]{2}{*}{ P-Value } & \multirow[t]{2}{*}{ Sig } \\
\hline & $\operatorname{High}(n=10)$ & SEM & $\operatorname{Med}(n=13)$ & SEM & $\operatorname{Low}(n=15)$ & SEM & & \\
\hline Total protein (mg/dl) & $5.79^{a}$ & 0.08 & $5.37^{\mathrm{b}}$ & 0.07 & $5.37^{\mathrm{b}}$ & 0.07 & 0.01 & * \\
\hline Albumin (mg/dl) & $3.18^{\mathrm{a}}$ & 0.04 & $3.10^{a b}$ & 0.04 & $3.03^{\mathrm{b}}$ & 0.04 & 0.05 & * \\
\hline Globulin (mg/dl) & $2.64^{a}$ & 0.11 & $2.22^{b}$ & 0.09 & $2.22^{b}$ & 0.09 & 0.01 & * \\
\hline Urea (mg/dl) & $62.70^{a}$ & 2.48 & $55.85^{b}$ & 2.72 & $52.93^{b}$ & 2.02 & 0.02 & * \\
\hline Creatinine (mg/dl) & $0.64^{b}$ & 0.06 & $0.79^{a}$ & 0.05 & $0.92^{\mathrm{a}}$ & 0.01 & 0.002 & $\star \star$ \\
\hline AST (U/L) & $162.90^{\mathrm{a}}$ & 10.29 & $120.35^{b}$ & 9.02 & $124.07^{b}$ & 8.41 & 0.01 & * \\
\hline CK (U/L) & 116.60 & 10.04 & 105.46 & 8.81 & 100.20 & 8.20 & 0.45 & NS \\
\hline
\end{tabular}

RFI was positively correlated with the concentrations of total serum protein, urea $(P=0.01)$ and globulin $(P=0.05)$, but negatively with creatinine level $(P=0.02)$. Although, FCR was positively correlated with total serum protein $(P=0.05)$ and AST $(P=0.001)$, the GFE was negatively correlated with AST ( $P=0.03)$ (Table 3 ). 
Table 3

Person correlation coefficients $(n=38)$ of blood biochemical components with residual feed intake $\left(r_{\text {RFI }}\right)$, feed conversion ratio $\left(r_{\mathrm{FCR}}\right)$ and gross feed efficiency $\left(\mathrm{r}_{\mathrm{GFE}}\right)$.

\begin{tabular}{|lllllll|}
\hline Parameters & $\mathrm{r}_{\mathrm{RFI}}$ & $\mathrm{P}$ & $\mathrm{r}_{\mathrm{FCR}}$ & $\mathrm{P}$ & $\mathrm{r}_{\mathrm{GFE}}$ & $\mathrm{P}$ \\
\hline Total protein & $0.44^{*}$ & 0.01 & $0.32^{*}$ & 0.05 & -0.30 & 0.06 \\
\hline Albumin & 0.17 & 0.30 & -0.004 & 0.98 & -0.001 & 0.90 \\
\hline Globulin & $0.31^{*}$ & 0.05 & 0.12 & 0.47 & -0.18 & 0.28 \\
\hline Urea & & & & -0.24 & 0.15 \\
\hline Creatinine & $0.40^{*}$ & 0.01 & 0.17 & 0.30 & 0.14 & 0.40 \\
\hline AST & $-0.37^{*}$ & 0.02 & -0.08 & 0.62 & $-0.35^{*}$ & 0.03 \\
\hline CK & 0.25 & 0.13 & $0.52^{* *}$ & 0.001 & -0.08 & 0.65 \\
\hline AST: Aspartate transaminase, CK: Creatinine Kinase. *: Statically significant $(P \leq 0.05)$ **: Statically significant $(P \leq 0.001)$. \\
\hline
\end{tabular}

\section{Residual feed intake and lipids profile:}

Table 4 shows the influence of RFI status on serum lipids profile. The results showed that there were no significant $(P>0.05)$ differences on all lipid parameters among RFI classes, with the exception to total lipids $(P=0.05)$ and HDL $(P=0.04)$ which were significantly different between high RFI and low RFI. A positive correlation was found between RFI and HDL ( $\mathrm{P}=0.002)$ and the most efficient $(\mathrm{LRF})$ animal showed the lowest concentration (Table 5).

Table 4

Means and SEM of lipid metabolites for Hamari lambs of different residual feed intake (RFI) classes

\begin{tabular}{|c|c|c|c|c|c|c|c|c|}
\hline \multirow[t]{2}{*}{ Parameters } & \multicolumn{6}{|l|}{ RFI classes } & \multirow[t]{2}{*}{ P-Value } & \multirow[t]{2}{*}{ Sig } \\
\hline & $\operatorname{High}(\mathrm{n}=10)$ & SEM & $\operatorname{Med}(n=13)$ & SEM & $\operatorname{Low}(n=15)$ & SEM & & \\
\hline Total lipids (mg/dl) & $23.57^{\mathrm{a}}$ & 1.56 & $21.85^{\mathrm{ab}}$ & 1.36 & $18.67^{b}$ & 1.27 & 0.05 & * \\
\hline $\mathrm{HDL}(\mathrm{mg} / \mathrm{dl})$ & $28.80^{\mathrm{a}}$ & 1.33 & $27.40^{a b}$ & 1.17 & $24.47^{b}$ & 1.10 & 0.04 & * \\
\hline LDL (mg/dl) & 19.55 & 0.72 & 19.92 & 0.63 & 19.53 & 0.59 & 0.89 & NS \\
\hline Cholesterol (mg/dl) & 52.20 & 2.30 & 47.92 & 2.02 & 46.71 & 1.88 & 0.18 & NS \\
\hline Triglycerides (mg/dl) & 29.60 & 1.31 & 27.39 & 1.16 & 27.00 & 1.08 & 0.29 & NS \\
\hline
\end{tabular}

HDL: High Density Lipoprotein. LDL: Low Density Lipoprotein. ${ }^{a-b}$ Means with different superscripts within a row are significantly different based on LSD comparison test $(P \leq 0.05)$. NS: Non-Significant difference $(P>0.05)$. *: Statically significant $(P \leq 0.05)$. SEM: standard error of means. 
Table 5

Person correlation coefficients $(n=38)$ of lipid biochemical components with residual feed intake $\left(\mathrm{r}_{\mathrm{RFI}}\right)$ and feed conversion ratio $\left(\mathrm{r}_{\mathrm{FCR}}\right)$ and gross feed efficiency $\left(r_{\mathrm{GFE}}\right)$.

\begin{tabular}{|c|c|c|c|c|c|c|}
\hline Items & $r_{\mathrm{RFI}}$ & $P$ & $\mathrm{r}_{\mathrm{FCR}}$ & $\mathrm{P}$ & $r_{\text {GFE }}$ & $\mathrm{P}$ \\
\hline Total lipids & 0.30 & 0.07 & 0.04 & 0.81 & -0.09 & 0.61 \\
\hline $\mathrm{HDL}$ & $0.52^{\star \star}$ & 0.001 & 0.18 & 0.27 & $-0.32^{\star}$ & 0.05 \\
\hline LDL & 0.08 & 0.65 & 0.21 & 0.21 & -0.23 & 0.16 \\
\hline Cholesterol & 0.22 & 0.19 & 0.12 & 0.46 & -0.12 & 0.46 \\
\hline Triglycerides & 0.23 & 0.17 & -0.11 & 0.51 & 0.08 & 0.65 \\
\hline \multicolumn{7}{|c|}{$\begin{array}{l}\text { HDL: High Density Lipoprotein, LDL: Low Density Lipoprotein. } \\
\text { *: Statically significant }(P<0.05) \text {. }\end{array}$} \\
\hline
\end{tabular}

\section{Residual feed intake and serum minerals profile:}

Results for serum mineral concentrations were presented in Table 6, there was no significant $(P>0.05)$ differences among RFI classes. Moreover, the same trend was observed to results of correlation between mineral metabolites and efficiency traits, with exception for phosphorus $(P=0.05)$ which was correlated positively with RFI (Table 7).

Table 6

Means and SEM of macro-minerals profile for Hamari lambs of different residual feed intake (RFI)

\begin{tabular}{|c|c|c|c|c|c|c|c|c|}
\hline \multirow[t]{2}{*}{ Items } & \multicolumn{6}{|l|}{ RFI classes } & \multirow[t]{2}{*}{$P$} & \multirow[t]{2}{*}{ Sig } \\
\hline & $\operatorname{High}(n=10)$ & SEM & $\operatorname{Med}(n=13)$ & SEM & $\operatorname{Low}(n=15)$ & SEM & & \\
\hline $\mathrm{Ca}(\mathrm{mg} / \mathrm{dl})$ & 9.10 & 0.35 & 8.54 & 0.31 & 9.20 & 0.29 & 0.26 & Ns \\
\hline $\mathrm{Cl}(\mathrm{mmol} / \mathrm{L})$ & 109.20 & 1.20 & 109.00 & 1.05 & 108.33 & 0.98 & 0.83 & Ns \\
\hline $\mathrm{K}(\mathrm{mmol} / \mathrm{L})$ & $4.40^{\mathrm{a}}$ & 0.22 & $4.53^{\mathrm{a}}$ & 0.19 & $4.31^{\mathrm{a}}$ & 0.18 & 0.71 & Ns \\
\hline $\mathrm{Mg}(\mathrm{mg} / \mathrm{dl})$ & 1.71 & 0.08 & 1.73 & 0.07 & 1.56 & 0.06 & 0.15 & Ns \\
\hline $\mathrm{Na}(\mathrm{mg} / \mathrm{dl})$ & 147.80 & 1.02 & 149.62 & 0.89 & 149.20 & 0.83 & 0.39 & Ns \\
\hline$P(m g / d l)$ & 5.13 & 0.13 & 4.94 & 0.11 & 5.17 & 0.11 & 0.31 & Ns \\
\hline \multicolumn{9}{|c|}{ Ca: Calcium, Cl: Chloride, K: Potassium, Mg: Magnesium, Na: Sodium, P: Phosphorus. } \\
\hline SEM: standar & D & & Significan & & $>0.05)$. & & & \\
\hline
\end{tabular}


Table 7

Person correlation coefficients $(n=39)$ of mineral biochemical components with residual feed intake $\left(r_{\mathrm{RFI}}\right)$ and feed conversion ratio $\left(\mathrm{r}_{\mathrm{FCR}}\right)$ and gross feed efficiency $\left(\mathrm{r}_{\mathrm{GFE}}\right)$

\begin{tabular}{|lllllll|}
\hline Items & $\mathrm{r}_{\mathrm{RFI}}$ & $\mathrm{P}$ & $\mathrm{r}_{\mathrm{FCR}}$ & $\mathrm{P}$ & $\mathrm{r}_{\mathrm{GFE}}$ & $\mathrm{P}$ \\
\hline $\mathrm{Ca}^{++}$ & 0.09 & 0.59 & 0.22 & 0.19 & -0.12 & 0.49 \\
\hline $\mathrm{Cl}^{-}$ & 0.10 & 0.54 & -0.14 & 0.41 & -0.04 & 0.81 \\
$\mathrm{~K}^{+}$ & 0.23 & 0.17 & 0.18 & 0.28 & -0.06 & 0.71 \\
\hline $\mathrm{Mg}$ & 0.08 & 0.65 & 0.08 & 0.64 & -0.20 & 0.23 \\
\hline $\mathrm{Na}^{+}$ & -0.11 & 0.52 & 0.01 & 0.94 & 0.11 & 0.50 \\
\hline $\mathrm{P}$ & $0.31^{*}$ & 0.05 & 0.26 & 0.12 & -0.12 & 0.46 \\
\hline $\mathrm{Ca}^{++}$: Calcium, $\mathrm{Cl}$ : Chloride, $\mathrm{K}^{+}$: Potassium, Mg: Magnesium, Na ${ }^{+}$: Sodium, P: Phosphorus. \\
\hline
\end{tabular}

\section{Discussion}

The objectives of this study were, to evaluate potential differences in feedlot performance, blood variables of lambs classified according to RFI, and to estimate correlation between feed efficiency represented by RFI, FCR, GF, and some metabolites blood parameters. The main findings of this study were; firstly, the low RFI animals had a greater GFE, and lower DMI and FCR values, with approximately a similar ADG and final body weight. Secondly; the RFI trait had a positive correlation with total protein, globulin, urea, HDL, phosphorus, and negative correlation with creatinine. FCR had a positive correlation with total protein and AST.

Consistent with our results, many previous studies have found variation in feed efficiency using the RFI approach between lambs, with the most efficient animals having lower dry matter intake $[7,17]$.

The mean values of RFI of the most efficient and least efficient group was $-0.28 \mathrm{Kg} \mathrm{DM} /$ day and $0.34 \mathrm{Kg} \mathrm{DM} /$ day, respectively, making a total difference of $0.62 \mathrm{Kg} \mathrm{DM} /$ day between the two groups. This difference was larger than the results found by Edson et al. [7] in their evaluation of Ile de France lambs, in which RFI values between efficiency groups ranged from -0.42 to $0.14 \mathrm{Kg} \mathrm{DM} /$ day. The results obtained for DMI, indicated that low RFI animals had $10.71 \%$ lower daily DMI than the med RFI animals and $14.28 \%$ than high RFI animals. This difference was slightly higher than the values of Low-RFI lle de France lambs, that had a $12.92 \%$ lower DMI than high-RFI lambs.

In the current study, the overall mean for ADG was 0.21 and $0.19 \mathrm{~kg} /$ day in low and high RFI groups, respectively. Basarab et al. [19] reported that the relationship between RFI and ADG was zero suggesting that RFI could be used as an indicator of the animal's maintenance requirements rather than growth, size and/or appetite. Therefore, RFI could become an important tool to increase profitability in the meat production industry. François et al. [20] and Snowder and VanVleck [21] reported a moderate heritability for RFI in sheep of 0.30 and 0.26 , respectively, which indicates the possibility of response to individual selection. However, it is essential to know the effects of using RFI as a genetic selection criterion in sheep.

A higher level of total protein, globulin, aspartate amino transferase and urea (the markers of liver function for higher protein catabolism) provide evidence for greater protein turnover in high RFI lambs than low RFI. The same results were demonstrated in previous studies in cattle, the high RFI animals had greatest total plasma protein levels [14]. The increasing level of blood protein may reflect the increasing rate of protein turnover in less efficient animals [22].

The higher globulin concentration in inefficient lambs may be associated with a greater stress response in these animals include an increase in metabolic rate and energy consumption coupled with increase in catabolic processes such as increased lipolysis and protein degradation [16]. Ricon-Delgado et al. [17], suggesting that less efficient sheep is on average more excitable or easily stressed than more efficient sheep.

The mean values of blood urea nitrogen $(\mathrm{BUN})$ differed significantly $(\mathrm{P}=0.02)$ between high and low $\mathrm{RFI}$ groups. A significant correlation $\left(\mathrm{r}_{\mathrm{FCR}}=0.40\right)$ was observed between RFI value and BUN concentration. Previous reports in cattle by Richardson et al. [14] have found greater blood concentrations of urea in less efficient genotypes. This may be due to a greater protein intake in high RFI animals, a greater rate of body protein degradation, or deviation in the supply of amino acids due in part to variation in the efficiency of microbial protein production in the rumen [23, 24]. Blood urea concentration has been reported as negatively correlated with high lean growth and positively correlated with backfat depth in sheep [25].

Creatinine is a metabolite product of creatine phosphate, an energy storage compound in the muscle, that has a positive association with muscle mass in sheep [25], cattle [26] and negatively with fat depth in sheep [25]. A negative correlation $(r=-0.38)$ between RFI and creatinine was shown in this study $(P=$ 0.02), a similar negative correlation ( $r=-0.45$ ) between serum creatinine and RFI for beef steers was observed by Richardson et al. [14]. Moreover, Richardson et al. [14] reported that animal selected for RFI may result in higher concentrations of blood creatinine and lead to changes in composition of the body with lower fat content in the carcass and a higher proportion of muscle mass in the carcass.

The mean values of AST activity were found to be 124.07 and $162.90(\mathrm{U} / \mathrm{L})$ in low and high RFI groups, respectively. AST is a key enzyme in amino acid metabolism and it acts as a marker of liver function and indicates higher levels of protein catabolism in the liver of less efficient steers [14]. Richardson and 
Herd [27] reported that the high level of AST was found in the cattle with high RFI. Therefore, metabolites may give indicator of differences in animal metabolism which may reflect genetics differences in feed efficiency.

The positive correlation between RFI and HDL ( ${ }_{\mathrm{RFI}}=0.49$ ), was in the same line with result obtained by Rauw et al. [28] who found that RFI tended to correlate positively with HDL.

Ions transport contributes $20 \%$ of the variation in basal energy expenditure between animals [29]. No strong correlation was observed between RFI and mineral concentrations except for phosphorus $\left({ }_{\mathrm{RFIr}}=0.32\right)$, which is essential for cellular biology and energy metabolism with implications for protein synthesis [30]. Higher concentrations of phosphorus in young cattle have been directly related to growth hormone activity, which promotes intestinal phosphate absorption and renal phosphate re-absorption [31]. Phosphorus also contributes to the production of the muscle storage molecules, kreatine phosphate and ATP [32].

\section{Conclusion}

The present study concluded that, although, all lambs of the different classes of RFI had similar average daily gain and final weight, the lambs with low RFI consumed less feed than the other groups. Moreover, RFI was positively correlated with urea, globulin, HDL, AST, phosphorus and negatively with creatinine. There are associations between RFI and feed utilization as reflected mainly by total protein, globulin, urea, creatinine, HDL and phosphorus.

\section{Methods}

\section{Study area}

The study was carried out at Faculty of Animal Production (Small Ruminant Research Unit), and laboratory of Department of Physiology, Faculty of Veterinary Medicine, University of Khartoum, during the period from July 2018 to October 2018.

\section{Experimental Animals}

Thirty-nine Hamari desert lambs were collected from Elnehoud locality, to ensure homogeneity within selected lambs following criteria were adopted: health, breed, body weight $(26.65 \pm 0.6 \mathrm{~kg})$ and age $(180 \pm 15$ days $)$.

\section{Housing, feeding management}

On arrival to the experimental site, each lamb was identified by an ear-tag then after they were treated against internal and external parasites. The animals were individually housed in elevated pens with a concrete sloped floor (approximately $1.5 \mathrm{~m} \times 1.5 \mathrm{~m} \times 2 \mathrm{~m}$ ) equipped with manual feeders and water sources. Ration was formulated to meet the nutrient requirement for growing lambs [18] (Table 8). Sheep were released after experiment.

Table 8

Ingredient and chemical composition of total mixed diet given to lambs

\begin{tabular}{|ll|}
\hline Ingredient & Inclusion \\
\hline Sorghum & \\
Groundnut cake & $26 \%$ \\
Groundnut hall & $20 \%$ \\
Molasses & $23 \%$ \\
Nacl & $30 \%$ \\
Lime stone & $0.5 \%$ \\
Chemical composition & $0.5 \%$ \\
Crude protein & \\
ME(MJ/Kg) & \\
& $14 \%$ \\
\hline ME: Metabolisable energy \\
\hline
\end{tabular}

\section{Residual feed intake determination}


After 15 days of adaptation to diet and management, the animals were kept confined for 90 days, the individual refusal feed was taken each morning allowing formation of weekly composite samples for the determination of $\mathrm{DM}$ and later to obtain observed dry matter intake (DMI $\mathrm{obs})$, which was calculated as difference between the amount of feed offered and the feed refused.

During the experimental period, lambs were weekly weighed and the average daily gain (ADG) was determined as the difference between final BW and initial BW divided by the experimental period. The RFI was measured as difference between the observed dry matter intake (DMI obs) and the estimated dry matter intake ( $\mathrm{DMl}_{\text {est }}$ ) [33]. The $\mathrm{DMl}_{\text {est }}$ was calculated by regressing the daily $\mathrm{DMI}_{\text {obs }}$ as function of metabolic $\mathrm{BW}(\mathrm{LWI}+\mathrm{LWM}+\mathrm{LWF} / 3)^{0.75}$; measured on days $(0,45$, 90) during the experimental period, and ADG, using R Development core Team statistical software (2010), following the model:

$\mathrm{DMI}_{\mathrm{est}}=\beta 0+\beta_{1} \mathrm{ADG}+\beta_{2} \mathrm{MBW}$

$\beta_{0}$ : regression intercept.

$\beta_{1}$ : partial regression coefficient of $\mathrm{DMI}_{\text {est }}$ on $\mathrm{ADG}$.

$\beta_{2}$ : partial regression coefficient of $\mathrm{DMI}_{\mathrm{est}}$ on $\mathrm{MBW}$.

After calculating the RFI coefficient for each animal, the lambs were classified into highest positive (least efficient; $>0.5 \mathrm{SD}$ above the mean $\mathrm{n}=10$ ) and (medium efficient; between \pm 0.5 SD from the mean $n=13$ ) and lowest negative (most efficient; $<0.5$ SD below the mean $n=17$ ), efficiency classes based on RFI.

Feed conversion was calculated as the ratio between DMI and ADG, whereas gross feed efficiency is its inverse, that is, the ratio between $A D G$ and $D M I$.

\section{Blood sampling and processing}

At the last weighing, blood samples were collected from 39 animals (after that one sample was waved due to hemolysis) via jugular vein puncture using plastic disposal syringes. The blood samples were allowed to stay for 1- 2 hours at room temperature and then centrifuged at 3000 rpm for 15 minutes to separate serum and stored at $-20^{\circ} \mathrm{C}$ until being analyzed.

\section{Blood analysis}

The serum total protein and albumin levels were estimated according to the methods of Grant et al. [34] and Doumas et al. [35], respectively. The serum globulin was calculated by subtracting the albumin from the obtained total protein [36]. The serum activities of aspartate aminotransferase (AST) and creatin kinas (CK) were determined according to the method of Reitman and Frankel [37]. The serum urea and creatinine level were measured according to the methods of Patton and Crouch [38] and Henry [39], respectively.

Serum total lipid, triglyceride, low density lipoprotein and high density lipoprotein were determined using analytical methods [40, 41, 42, 43], respectively. Cholesterol (enzymatic colorimetric method of cholesterol oxidase-peroxidase-4-aminophenazone).

Serum calcium concentration was determined by colorimetric method [44]. Phosphorus concentration (mg/dl) in serum was determined by methods described by Farrell [45]. Serum sodium, potassium and chloride were determined by colorimetric method described by Kim et al. [46].

\section{Experimental design and Statistical analysis}

The experimental protocol was approved by the research board of the Faculty of Animal Production, University of Khartoum, Sudan (RB 2016/126) and was in accordance with institutional and national guidelines for the care and use of animals.

Data from different efficiency groups were subjected to analysis of variance (ANOVA) for a completely randomize design to verify the difference by $F$ test at $5 \%$ significance, and the least significant difference (LSD) was used to mean separation. The Residual feed intake correlations with the mean values of blood variables were estimated by person's simple correlation analysis using the Cor-test analytical procedure of the R Development core Team (2010) statistical program to separate between means.

\section{Abbreviations}




\begin{tabular}{ll} 
Alanine aminotransferase & AST \\
\hline Average daily gain & ADG \\
\hline Body weight & BW \\
\hline Creatinine Kinase & CK \\
\hline Dry matter intake & DM \\
\hline Estimated dry matter intake & DM ${ }_{\text {est. }}$ \\
\hline Feed conventional ratio & FCR \\
\hline Gross feed efficiency & GFE \\
\hline High density lipoprotein & HDL \\
\hline Low density lipoprotein & LDL \\
\hline Ministry of Animal Resources and Fisheries & MARF \\
\hline Metabolic body weight & MBW \\
\hline energy & ME \\
\hline Observed dry matter intake & DM ${ }_{\mathrm{obs}}$ \\
\hline Residual feed intake & RFI
\end{tabular}

\section{Declarations}

\section{Ethics approval and consent to participate}

The experimental protocol was approved by the research board of the Faculty of Animal Production, University of Khartoum, Sudan (RB 2016/126) and was in accordance with institutional and national guidelines for the care and use of animals. The Animal Production Research Board approved this study without ethics approval, this is because the study depends only on feeding and collecting blood samples from the sheep. The animals were released after experiment. Animals were owned by Department of Animal Nutrition- faculty of Animal Production, UofK. Written informed consent to use the animals in the study was obtained from the owner of the animals.

\section{Consent for publication}

Not Applicable

\section{Availability of data and materials}

The datasets used and/or analyzed during the current study are available from the corresponding author on reasonable request.

\section{Competing interests}

All other authors declare no competing interests.

\section{Funding}

The research was funded by grant from the Ministry of Higher Education, Sudan (2016/4) (offered the money).

\section{Authors' contributions}

BA and TA contributed to the study design and execution, sample collection, sample analysis and was responsible for interpretation of analyzed data, and preparation of the manuscript. All authors read and approved the final manuscript.

\section{Acknowledgements}

The authors would like to express their gratitude to the Department of Animal Nutrition (Small Ruminant Research Unit), Faculty of Animal Production and laboratory of Department of Physiology, Faculty of Veterinary Medicine, University of Khartoum for supporting experimental facilities. 


\section{Author information}

Balgees, A. AttaElmnan and Tayseer Abass Karar Ali

\section{Affiliations}

Department of Animal Nutrition- Faculty of Animal Production

University of Khartoum, 13314 Khartoum, Sudan

\section{References}

1. Ministry of Animal Resources and Fisheries, department of statistic and information, Annual Report, Khartoum, Sudan 2018.

2. Farah SE. Feedlot performance and carcass characteristics of kunanned and intact Sudanese desert sheep. M.Sc. Thesis 2004 , Sudan University of Science and Technology- Sudan.

3. Wilson RT. Populations and production of fat-tailed and fat-rumped sheep in the Horn of Africa. Trop Anim Health Prod. 2011; 43:1419-1425. https://doi.org/10.1007/s11250-011-9870-9.

4. Moore SS, Mujibi FD, Sherman EL. Molecular basis for residual feed intake in beef cattle. Anim. Sci. 2009;87 (Suppl. 14):41-47.

5. Herd RM, Archer JA, Arthur PF. Reducing the cost of beef production through genetic improvement in residual feed intake, Opportunity and challenges to application. J Anim. Sci. 2003;81:9-17.

6. Field TG, Taylor RE.' Beef Production and Management Decisions, (4th ed) Prentice Hall, Upper Saddle River, New Jersey.

7. Edson FEP, Damaris FS, Alda Lúcia GM, Miguel HAS, Susana G, Paulo R, Rosangela LD. Residual feed intake and hematological and metabolic blood profiles of lle de France lambs. R Bras Zootec. 2013;42:11.

8. Herd RM, Arthur PF, Bottema CDK, Egarr AR, Geesink GH, Lines DS, Piper S, Siddell JP, Thompson JM, Pitchford Genetic divergence in residual feed intake affects growth, feed efficiency, carcass and meat quality characteristics of Angus steers in a large commercial feedlot. Anim. Prod. Sci. 2018; 58(1):164-174.

9. Richardson EC, Herd RM, Oddy VH. Variation in body composition, activity and other physiological processes and their associations with feed efficiency in 'feed efficiency in beef cattle. Proceedings of the feed efficiency workshop, (Eds JA Archer, RM Herd and PF Arthur) (University of New England, Armidale, NSW, Australia). 2000; 46- 50.

10. Nkrumah JD, Okine EK, Mathison GW, Schmid K, Li C, Basarab JA, Price MA, Wang Z, Moore Relationships of feedlot feed efficiency, performance, and feeding behavior with metabolic rate, methane production, and energy partitioning in beef cattle. J Anim Sci. 2006;84:145-153.

11. Montanholi YR, Swanson KC, Palme R, Schenkel FS, McBride BW, Lu D, Miller SP. Assessing feed efficiency in beef steers through feeding behavior, infrared thermography and glucocorticoids. Anim. 2010;4: 692-701.

12. Ferrell CL. Contribution of visceral organs to animal energy expenditures. J Anim Sci. 1988;66:23-34.

13. Kolath WH, Kerley MS, Golden JW, Keisler The relationship between mitochondrial function and residual feed intake in Angus steers. J Anim Sci. 2006;84(4):861-5.

14. Richardson EC, Herd RM, Archer JA, Arthur PF. Metabolic differences in Angus steers divergently selected for residual feed intake. Aust J Expt Agric. (2004);44: 441- 452.

15. Knott AB, Perkins G, Schwarzenbacher R, Bossy-Wetzel E. Mitochondrial fragmentation in neurodegeneration. Nat Rev Neurosci. 2008;9(7):505-18.

16. Redden RR, Surber LMM, Grove AV, Kott RW. Growth efficiency of ewe lambs classified into residual feed intake groups and pen fed a restricted amount of feed. Sm Rum Res. 2013;114:214-219.

17. Ricon-Delgado RM, Perez-Vazquez ED. Relationship of residual feed intake on specific hematological and biochemical parameters in Rambouillet sheep. Anim Vet Adv. 2011;10:1112-1116.

18. Nutrient requirements for small ruminants. National Academy Press, Washington, D.C, United States. 2006;362.

19. Basarab JA, Price MA, Aalhus JL. Residual feed intake and body composition in young cattle. Canad J Anim Sci. 2003;83(2):189-204.

20. François D, Bibe D, Brunel JB. Genetic parameters of feeding traits in meat sheep. In: world congress on genetics applied to livestock production, Proceedings... Montpellier, 2002;7:233-236.

21. Snowder GD, Van Vleck LD. Estimates of genetic parameters and se-lection strategies to improve the economic efficiency of post weaning growth in lambs. J Anim Sci. 2003;81:2704-2713.

22. Richardson EC, Herd RM. Biological basis for variation in residual feed intake in beef cattle. Aust J Exp Agric. 2004;44:431-440.

23. Lush JM, Gooden JM, Annison EF. The uptake of nitrogenous compounds from the gut of sheep genetically different in wool production. Proceedings of the Nutrition Society of Australia. 1991;16: 144.

24. Kahn L.P, Leng RA, Piper LR. Rumen microbial yield from sheep genetically different for fleece weight. Asian-Australas J Anim Sci. $2000 ; 13: 137$.

25. Clarke JN, Binnie, DB, Jones, KR, Mowat CM, Purchas RW, Uljee AE. Repeatability of blood plasma metabolites and their associations with leanness in genotypes showing a wide divergence in carcass composition. Proceedings of the New Zealand Society of Animal Production. 1996;56:180-183. 
26. Ishaq SL, Kim CJ, Reis D, Wright ADG. Fibrolytic bacteria isolated from the rumen of North American moose (Alces alces) and their use as a probiotic in neonatal lambs. PloS ONE. 2015;10 (12):144804.

27. Richardson EC, Herd RM. Biological basis for variation in residual feed intake in beef cattle. 2. Synthesis of results following divergent selection. Aust $J$ Exp Agric. 2004; 44:431-440.

28. Rauw WM, Johnson AK, Gomez-Raya L, Dekkers JCM. A hypothesis and review of the relationship between selection for improved production efficiency, coping behavior, and domestication. Front Genet. 2017; 8:134.

29. Bottje, W.G and Carstens, G.E (2009). Association of mitochondrial function and feed efficiency in poultry and livestock species. J Anim Sci. 87; $48-63$.

30. Suttle Mineral Nutrition of Livestock. 2010;4th Ed. Commonwealth Agricultural Bureaux International, Oxfordshire, UK.

31. Myer PR, Smith TPL, Wells JE, Kuehn LA, Freetly HC. Rumen microbiome from steers differing in feed efficiency. PLoS ONE. 2015;10:1-17.

32. Huber K, Breves G. Influence of dietary phosphorus depletion on central pathways of intermediary metabolism in rats. Arch Anim Nutr. 1999;52: 299309.

33. Koch RM, Swiger LA, Chambers D, Gregory KE. Efficiency of feed uses in beef cattle. J Anim Sci. 1963;22: 486- 494.

34. Grant GH, Silverman LM, Christenson RH. Aminoacids and proteins. Fundamental of Clinical Chemistry. 1987;3th ed. WB Saunders Company; Philadelphia.

35. Doumas BT, Watson WA, Biggs HG. Albumin standards and measurement of serum albumin with bromocresol green. Acta. 1971;87-96.

36. Doumas BT, Bayso DD, Carter RJ, Peter T, Schaffer R. Determination of serum albumin. Clin Chem. 1981;27:1642.

37. Reitman S, Frankel S. Colorimetric method for determination of serum transaminases activities. Am J Clin Path. 1957;28:56-68.

38. Patton CJ, Crouch SR. Enzymatic determination of urea. Anal Chem. 1977;49:464-469.

39. Henry TJ. Clinical Chemistry Principles and Techniques. 1974;2th ed. Harper and Row Publishers; New York.

40. Frings CS, Duun R.T. Determination of total lipids based on the color obtained by phosphovaniline after digestion in sulphuric acid conc. Anim J ClinPath. 1970;53: 89-91.

41. Fossati P, Prencipe L. Serum triglycerides determined calorimetrically with an enzyme that produces hydrogen peroxide. Chin Chem. 1982;28: 2077-2080.

42. Assmann G, Jabs HU, Kohnert U, Nolte W, Schriewer H. LDL-cholesterol determination in blood serum following precipitation of LDL with polyvinylsulfate. Clin Chem Acta. 1984;140: 77-83.

43. Burstein M, Scholnick HR, Morfin R. Rapid method for the isolation of lipoprotein from human serum by precipitation with polyanious. Scand J Clin Lab Invest.1980;40:583-595.

44. Gindler EM, King JD. Rapid colorimetric determination of calcium in biologic fluids with methylthymol blue. Am J Clin Pathol. 1972;58(4):76-82.

45. Farrell CE. Electrolytes. In clinical chemistry theory. Analysis and correlation. The C.V. Mosby Company. Kaplan L.A., Pesce. A.J (Ed). (1984); $55: 1054$.

46. Kim EK, Waddell LD, Logan JE. Clin Chem. 1972;18(2):124.

\section{Supplementary Files}

This is a list of supplementary files associated with this preprint. Click to download.

- NC3RsARRIVEGuidelinesChecklistdalia11.pdf 